\title{
Federal Immunity from State Taxation: A Reassessment
}

The power to tax is one of the most important incidents of sovereignty. In a system of government that in theory recognizes the sovereignty of the states as well as of the federation of those states, it is inevitable that conflicts will arise from attempted taxation of governmental instrumentalities. The American Constitution does not speak to such conflicts directly. Although the Constitution expressly prohibits state taxation of exports and imports, ${ }^{1}$ no provision of the Constitution prohibits either federal taxation of state instrumentalities, or state taxation of federal instrumentalities, and no provision expressly preserves the power of either sovereign to tax the other. Intergovernmental tax immunities have nonetheless been implied by the federal courts. ${ }^{2}$

Federal immunity from state taxation derives from the Marshall Court's decision in McCulloch v. Maryland. ${ }^{3}$ In $M c C u l l o c h$, and in the later case of Weston $v$. City Council, ${ }^{4}$ John Marshall fashioned a doctrine of absolute federal tax immunity. The absolute immunity doctrine was greatly restricted in the decades after $\mathrm{McCulloch}$, as the Supreme Court narrowed the domain of entities and activities absolutely protected from state taxation, but the core of the doctrine remains. At present, the protected domain is defined by the rule of "legal incidence": state taxation that falls directly upon (is legally incident upon) federal instrumentalities is forbidden. Taxes that financially burden federal activities but are not legally incident on federal instrumentalities are permitted provided they do not discriminate against or severely interfere with federal operations.

Of all the constitutional limitations on sovereign powers of taxation, the current limitations on state taxation of federal instrumentalities appear the most formalistic, the most divorced from their original purposes. John Marshall devised federal tax immunity in order to safeguard federal operations from potentially destructive

I The import-export clause, U.S. ConST. art. I, § 10, cl. 2, provides in relevant part: "No state shall, without the Consent of the Congress, lay any Imposts or Duties on Imports or Exports, except what may be absolutely necessary for executing its inspection Laws . . . ."

2 Federal immunity from state taxation was first implied in McCulloch v. Maryland, 17 U.S. (4 Wheat.) 316 (1819). State immunity from federal taxation originated with the Court's decision in Collector v. Day, 78 U.S. (11 Wall.) 113 (1871).

317 U.S. (4 Wheat.) 316 (1819).

' 27 U.S. (2 Pet.) 449 (1829). 
state taxation. This comment argues that federal tax immunity doctrine has forgotten its origins and hence its purposes. Part I traces the development of federal immunity doctrine from $\mathrm{McC}$ Culloch to the present, and shows that the formalism of current doctrine is a natural consequence of Chief Justice Marshall's approach to the question raised by the $\mathrm{McCulloch}$ case. Part II examines developments in related areas of constitutional limitations on taxing powers that reveal the Supreme Court's rejection of absolute immunities in favor of a functional approach to taxing power limitations. Part III tests current federal tax immunity law against the purposes of intergovernmental tax immunity doctrine and demonstrates its inadequacy. Part IV argues that state and federal interests would be best accommodated were the courts to permit state taxation of federal instrumentalities, subject to the limitation that the taxation not discriminate against or seriously interfere with the operations of those instrumentalities.

\section{The Background and Basis of Federal Tax Immunity Doctrine}

\section{A. Background}

In McCulloch v. Maryland the Court confronted the question of intergovernmental taxation for the first time. Under challenge was a Maryland tax on the Bank of the United States. The tax statute provided that banks operating in Maryland "without authority from the state" (the description fit only the Bank) could issue bank notes only on stamped paper sold by the state. ${ }^{7}$ Chief Justice Marshall, in a circumspectly ambiguous opinion for the Court, construed the Constitution to forbid the tax. Parts of the opinion seem to say that state powers of taxation, by the very nature of the federal system, do not extend to federal instrumentalities. ${ }^{8} \mathrm{~A}$ reading more consistent with the opinion as a whole, however, is that the result was rooted in the supremacy of national law commanded by the supremacy clause. The Bank, reasoned Marshall, was a creature of federal law, and its operations the operations of federal law. ${ }^{9}$ Since the power to tax, in his famous dictum, is the power to destroy, ${ }^{10}$ Maryland's effort to tax the Bank's operations

517 U.S. (4 Wheat.) 316 (1819).

- Id. at 320 .

7 Id. at 321.

8 This is Professor Charles Black's reading of $\mathrm{McCulloch}$. He has cited $\mathrm{McCulloch}$ as a prime illustration of "structuralist" constitutional reasoning. C. BLACK, STRUCTURE ANd RELATHONSHIP IN CONSTITUTIONAL LAW 15 (1969) [hereinafter cited as Black].

17 U.S. (4 Wheat.) at 431.

${ }^{10}$ Id. at $427,431$. 
amounted to the assertion of a state power to frustrate the operation of federal law-an effort prohibited by the supremacy clause." To the state's protests that the assertion of the power to tax is not an assertion of the power to destroy-because the taxing power could be exercised with restraint-Marshall's answer was twofold. First, by erecting a per se rule against such taxation, the Court could avoid the "perplexing inquiry, so unfit for the judicial department, what degree of taxation . . . may amount to the abuse of power."12 Second, short of absolute prohibition, the federal government lacked the means of assuring state restraint. "The only security against the abuse [of the taxing power] is found in the structure of the government itself,"13 Marshall declared. Lacking the sole structural safeguard against abusive taxation-political representation in state legislatures-the federal government needed the protection of an absolute immunity from state taxation. ${ }^{14}$

Dicta at the conclusion of the Chief Justice's opinion created real doubt about the scope of the decision. Marshall observed:

This opinion does not deprive the states of any resources which they originally possessed. It does not extend to a tax paid by the real property of the bank, in common with other real property within the state, nor to a tax imposed on the interest which citizens of Maryland may hold in this institution in common with other property of the same description throughout the state. But this is a tax on the bank's operations . . . . ${ }^{15}$

This reservation has understandably suggested to some commenta-

" Id. at 432. Professor Black finds the supremacy clause "not a very satisfying rationale, for article VI declares the supremacy of whatever the national law may turn out to be, and does not purport to give content to that law." BLACK, supra note 8 , at 15 . This view is premised on a fairly modern conception of the supremacy clause. The question facing Marshall was not whether national law (other than constitutional law) demanded tax immunity, and thus overrode state tax law, but whether state law could be permitted to set at nought the operations of federal law. Marshall viewed $\mathrm{McCulloch}$ as raising the question of nullification. He prefaced his discussion of the issue with the following:

The great principle is, that the constitution and the laws made in pursuance thereof are supreme .... From this, which may be almost termed an axiom, other propositions are deduced as corollaries . . . . These are, 1st. that a power to create implies a power to preserve. 2d. That a power to destroy, if wielded by a different hand, is hostile to, and incompatible with these powers to create and to preserve. $3 \mathrm{~d}$. That where this repugnancy exists, that authority which is supreme must control, not yield to that over which it is supreme.

17 U.S. (4 Wheat.) at 426.
12 Id. at 430.
${ }^{13}$ Id. at 428 .
"Id. at 431 .
is Id. at 436 . 
tors that the Court's absolute prohibition of taxes upon government operations applied only to tax laws that discriminate against federal operations..$^{16}$ Indeed, the two examples of permissible taxation cited by Marshall share the feature of nondiscrimination against the federal government. This reading of the reservation is supported by Marshall's second reason for concluding that the power to tax, in this case, amounted to the power to destroy-the lack of structural safeguards. Nondiscriminatory taxes, which burden federal agents no more than they do other entities and persons resident in the state, are unlikely, for structural reasons, to be imposed destructively. The citizens of the state, who are represented in the state legislature, are unlikely to sacrifice their own financial interests to the extent necessary to subvert the operations of the federal government. Thus, as Justice Johnson was to point out in Weston v. City Council, ${ }^{17}$ the reasons for the per se rule were inapplicable to nondiscriminatory taxes. An alternative reading of the reservation is that Marshall was drawing a distinction between, on the one hand, taxes falling on resources that "belonged" to the state before the Bank began business and, on the other, taxes falling on the Bank's operations. Under this reading, federal immunity would not extend to the realty of federal instrumentalities, nor to property of state citizens that the instrumentality might employ in its operations. ${ }^{18}$

In its next confrontation with a federal immunity question, the Court expanded the absolute immunity doctrine. In Weston $v$. City Council ${ }^{19}$ the Court invalidated a tax on interest income on federal government bonds, a tax very difficult to distinguish from the second example of a permissible tax set forth by Chief Justice Marshall in $\mathrm{McCulloch}$. The tax, according to Justice Johnson's dissenting opinion, was not discriminatory, but was part of a larger scheme of

18 See Justice Thurgood Marshall's dissent in First Agr. Nat'l Bank v. State Tax Comm'n, 392 U.S. 339 (1968), suggesting: "One could, and perhaps should, read M'Culloch . . . simply for the principle that the Constitution prohibits a state from taxing discriminatorily a federally established instrumentality." 392 U.S. at 350 (Marshall, J., dissenting). See also Hellerstein, State Taxation and the Supreme Court: Toward a More Unified Approach to Constitutional Adjudication? 75 Mich. L. REv. 1426, 1453 (1977); Ratchford, Intergovernmental Tax Immunities in the United States, 6 NaT'L TAX J. 305, 307, 308 (1953); Pierce, Tax Immunity Should Not Mean Tax Inequity, 1959 WIs. L. REv. 173, 177.

1727 U.S. (2 Pet.) 449, 472-73 (1829) (Johnson, J., dissenting).

${ }_{18}$ Authorities have suggested that this was the distinction Marshall contemplated. See, e.g., S. Konersky, Chief Justice Stone and the Supreme Court 6 (1945) [hereinafter cited as Konersky]; cf. United States v. City of Adair, 539 F.2d 1185, 1190 (8th Cir. 1976), cert. denied, 429 U.S. 1121 (1977) ("McCulloch seems to make clear, in dictum, the principle that a tax on the real property of a government instrumentality is not constitutionally prohibited because it is not a tax on the operations or means of the federal government.").

1927 U.S. (2 Pet.) 449 (1829). 
bond interest taxation. ${ }^{20}$ The Chief Justice, speaking for the majority, made it clear, however, that the distinction drawn in the conclusion of the McCulloch opinion was not a distinction between discriminatory and nondiscriminatory taxes, but one between taxes on federal operations and taxes on federal property in the state. ${ }^{21}$ The "tax on government stock," said Marshall, was a tax on the bond contract, and hence "a tax on the power to borrow money on the credit of the United States." 22 The tax fell on "an operation essential to the important objects for which the government was created,"23 and was therefore a per se abuse under the reasoning of $\mathrm{McCulloch}$.

Chief Justice Marshall's conceptualism, and perhaps his will to advance the interest of the national government, blinded him to serious practical difficulties with his approach. In cutting off the possibility that federal immunity law might proceed under the aegis of the nondiscrimination principle championed by Justice Johnson, he condemned the Supreme Court to a long and difficult career of distinguishing between taxation of federal agents' property and taxation of their activities on behalf of the federal government. Marshall's reasoning in $\mathrm{McCulloch}$ and Weston spawned an intricate conceptualist jurisprudence that, by 1873 , had Supreme Court justices strenuously debating whether a California tax on a federally chartered railroad's property fell on the railroad's federal franchise (in which case it would be an impermissible tax on federal operations) or merely on its state franchise (in which case it would be a permissible tax on a federal agent's property). ${ }^{24}$ The $\mathrm{McC}$ Culloch Court had found attractive an absolute prohibition of state taxation burdening federal operations in part because a per se rule would avoid the "perplexing inquiry, so unfit for the judicial department, what degree of taxation is the legitimate use." 25 Try as it might to define the scope of that absolute prohibition in the century following Weston, the Court became enmeshed in what now appears to have been virtually case-by-case adjudication of "what degree of taxation is the legitimate use."

20 Id. at $472-73$ (Johnson, J., dissenting). The tax at issue in Weston would today be considered discriminatory since it was not imposed on the interest income from state bonds. See Phillips Chem. Co. v. Dumas Independent School Dist., 361 U.S. 376 (1959); text and note at note 67 infra.

2t 27 U.S. (2 Pet.) at $468-69$.

22 Id. at 469.

23 Id. at 467.

24 Union Pac. R.R. v. Peniston, 85 U.S. (18 Wall.) 5 (1873). The property/operations distinction was only important where private entities claimed immunity, for real property owned by the United States, Marshall's McCulloch dictum notwithstanding, was eventually immunized from state taxation. Van Brocklin v. Tennessee, 117 U.S. 151 (1886).

25 McCulloch v. Maryland, 17 U.S. (4 Wheat.) 316, 430 (1819). 
Not only did the absolute immunity doctrine frustrate the $\mathrm{McC}$ Culloch ideal of administrability, but it also led, as the federal government's role in the economy expanded, to a deprivation of state taxing power that seemed unjustified by the benefits it afforded the federal government. The prohibition against taxes burdensome to federal operations resulted in the invalidation of many state taxes assessed against private entities selling goods and services to the federal government. The Court, in the years following Weston, held unconstitutional gross receipts taxes on government contractors, ${ }^{28}$ income taxes on the wages of federal employees, ${ }^{27}$ and taxes on the profits derived from exploitation of oil and gas leases of restricted Indian lands, ${ }^{28}$ and even license taxes on the business of a telegraph company performing Postal Office work. ${ }^{29}$. As the federal government's commercial role increased, the volume of taxexempt activity increased, depriving the states, by the end of the first quarter of this century, of vast amounts of needed revenue. A change was clearly needed, and it came, in 1937, with the majority opinion of Chief Justice Hughes in James $v$. Dravo Contracting Co ${ }^{30}$

\section{B. The Origins of Current Legal Incidence Doctrine}

The structure of the current law of federal tax immunity from state taxation derives largely from Chief Justice Hughes's bold "restatement" of the law in his opinion for the Court in James $v$. Dravo Contracting Co. ${ }^{31}$ In Dravo the Court turned its back on clear and overwhelming precedent ${ }^{32}$ in holding that a state can impose a nondiscriminatory tax on the gross receipts reaped by a private contractor under a construction contract with the federal government. Chief Justice Hughes buttressed a long and labored effort to distinguish the precedents by reproducing the following passage from a Supreme Court decision on state immunity from federal taxation:

\footnotetext{
${ }^{26}$ E.g., Panhandle Oil Co. v. Mississippi ex rel. Knox, 277 U.S. 218 (1928) (state sales tax on gasoline).

${ }^{27}$ E.g., Dobbins v. Commissioners of Erie County, 41 U.S. (16 Pet.) 435 (1842).

2 E.g., Gillespie v. Oklahoma, 257 U.S. 501 (1922); Choctaw, Okla. \& G. R.R. v. Harrison, 235 U.S. 292 (1914). The lessees were considered instrumentalities of the government for the purpose of aiding the government in fulfilling its obligations to the Indian tribes.

2 E.g., Leloup v. Port of Mobile, 127 U.S. 640 (1888).

30302 U.S. 134 (1937).

31 Id.

32 The extent of the Court's break with precedent is suggested by Justice Roberts's scholarly dissenting opinion. See id. at 161-86 (Roberts, J., dissenting) and cases cited therein.
} 
The power to tax is no less essential than the power to borrow money, and, in preserving the latter, it is not necessary to cripple the former by extending the constitutional exemption from taxation to those subjects which fall within the general application of nondiscriminatory laws, and where no direct burden is laid upon the governmental instrumentality and there is only a remote, if any, influence upon the exercise of the functions of the government. ${ }^{33}$

Chief Justice Hughes's creative synthesis of the precedents represented a conscious effort to accommodate competing state and federal interests and a partial rejection of the absolutism of $M c C u l l o c h$ and Weston. The formula that emerged from Dravo was a peculiar admixture of the pragmatic nondiscrimination principle suggested by $\mathrm{McCulloch}$ and the difficult-to-apply economic burden rule of Weston. Chief Justice Hughes both revived the nondiscrimination principle, dormant since $\mathrm{McCulloch}$, and took a large step in the direction of burying the confusing distinction between impermissible taxation of governmental operations and permissible taxation of a governmental agent's property employed in carrying out those operations. Nevertheless, the Court refrained from generalizing the nondiscrimination principle. The Court suggested that even a nondiscriminatory tax would nevertheless be barred if it imposed "a direct burden" upon a governmental instrumentality, or if it had fairly immediate impact on the exercise of a governmental function. ${ }^{34}$

Two principal Supreme Court cases shaped the new doctrine of federal tax immunity adumbrated in Dravo. Dravo itself left unclear the boundaries of the domain governed by the nondiscrimination principle. In dictum in that opinion, Chief Justice Hughes denied that the result would have been any different had the economic burden of the tax fallen wholly on the government. ${ }^{35}$ Hughes's dictum became law when the Court, in Alabama v. King \& Boozer, ${ }^{36}$ upheld Alabama's authority to collect a sales tax from a government contractor performing a cost-plus-fixed-fee contract. The Court held that the nondiscriminatory character of the tax made it permissible, even though the full economic burden of the tax indisputably fell

Id. at 150 (quoting Willcuts v. Bunn, 282 U.S. 216, 225 (1931)).

3 Id. at 149-50. Cf. Willcuts v. Bunn, 282 U.S. 216, 225 (1931) (state immunity from federal taxation). Interestingly, the Solicitor General urged the Court in the Dravo case to adopt a nondiscrimination test for the constitutionality of all state taxation burdening federal operations. 302 U.S. at 170-71 (Roberts, J., dissenting).

302 U.S. at 160.

× 314 U.S. 1 (1941). 
on the government. ${ }^{37}$ In Mayo v. United States ${ }^{38}$ however, the Court drew the line. Both Dravo and King \& Boozer involved taxes levied on private entities selling goods and services to the government, and thus did not raise the issue whether direct taxation of federal instrumentalities was permissible. In Mayo, the Court sharply distinguished those cases, and held that taxes charged directly against the United States are per se forbidden. ${ }^{39}$

The cases following Dravo suggest that the primary issue facing courts determining claimed federal immunities is whether the tax in question falls on the person with whom the government is transacting, in which case nondiscriminatory taxation is permissible, or on the government itself, in which case it is not. For the old property/operations distinction, formerly applied when a state tax fell on an agent of the federal government, ${ }^{40}$ the new doctrine of "legal incidence" substituted the distinction between government and non-government entities. Later cases added the requirement, derived from Dravo, that nondiscriminatory taxes not legally incident on the government (as in King \& Boozer) must also not unduly burden federal operations. ${ }^{41}$

\section{The Legal Incidence Doctrine}

The doctrine that emerged from Dravo is a considerable improvement, in terms of administrability, over the economic burden doctrine of Weston. Nevertheless, the legal incidence doctrine is somewhat complex and is rife with much of the formalism that characterized the earlier doctrine. Only a survey of the rule's operation can adequately convey its difficulties. In general, courts will invoke the rule's per se prohibition only after affirmatively answering three questions. First, whom does the taxing statute purport to tax? Second, has the statutory incidence been effectively altered by contract? Third, is the party on whom the tax is legally incident (by statute or contract) a part of the federal government or otherwise entitled to claim the government's immunity?

1. Statutory Incidence. In Alabama v. King \& Boozer, ${ }^{42}$ the Court left to state law the question of who was the "purchaser" and

${ }^{37}$ Id. at $8-9$.

38 319 U.S. 441 (1943). In Mayo, the Court found a Florida state fee for inspection of fertilizer owned by the federal government to be a tax on the government.

${ }^{39} \mathrm{Id}$. at $447-48$.

to E.g., Owensboro Nat'l Bank v. Owensboro, 173 U.S. 664 (1899); Union Pac. R.R. v. Peniston, 85 U.S. (18 Wall.) 5 (1873).

"See note 68 infra.

12314 U.S. 1 (1941). 
hence on whom the sales tax in question was legally incident. Recent Supreme Court decisions, however, suggest that state law determination of legal incidence does not control, and perhaps is only entitled to minimal deference. In the case of Diamond National Corp. v. State Board of Equalization,,$^{43}$ for example, the Court ignored forty years of consistent state court precedent in holding that the tax in question fell on the purchaser (a national bank) rather than the vendor. ${ }^{44}$

The federal courts have employed several factors to locate statutory incidence. Statutory liability for the tax does not equal statutory incidence; the Supreme Court has reversed lower court cases holding the two equivalent. ${ }^{45}$ Rather, the Court seems to rely on its determination of who the legislature intended to actually pay the tax, who may, but need not, be the party made legally responsible for the payment. ${ }^{46}$ The Supreme Court established early and adheres to the view that the economic burden of a tax is irrelevant in determining statutory incidence. ${ }^{47}$ But recent cases suggest that economic burden may be evidence of legislative intent as to who should pay the tax. For example, in United States v. Mississippi Tax Commission, ${ }^{48}$ a Tax Commission regulation imposed a $17-20 \%$ markup on liquor sales by the state-owned wholesalers to military installations. The Supreme Court found direct evidence that the Tax Commission intended for the purchaser and not the wholesaler to pay the $\operatorname{tax}^{48}$ but added, "even in the absence of this clear statement of the Tax Commission's intentions, obviously economic realities compelled the distillers to pass on the economic burden of the markup." ${ }^{50}$ In sum, statutory incidence depends not on legal liability for the tax but on legislative intent, and economic realities may be strong indication of that intent.

2. Alteration of Statutory Incidence by Contract. The "statutory incidence" of a tax does not alone determine whether the legal incidence of a tax is on the government. According to the Su-

425 U.S. 268 (1976).

"Id. at 268. Justices Stevens and Rehnquist dissented from this holding. Id. at 271 n.7.

45 United States v. Mississippi Tax Comm'n, 378 F. Supp. 558 (S.D. Miss. 1974), rev'd, 421 U.S. 599 (1975); First Agr. Nat'l Bank v. State Tax Comm'n, 353 Mass. 172, 229 N.E.2d 245 (1967), rev'd, 392 U.S. 339 (1968).

s United States v. Mississippi Tax Comm'n, 421 U.S. 599, 607-09 (1975); First Agr. Nat'l Bank v. State Tax Comm'n, 392 U.S. 339, 347-48 (1968).

" Alabama v. King \& Boozer, 314 U.S. 1, 8 (1941); Gurley v. Rhoden, 421 U.S. 200, 20405 (1975).

t\$ 421 U.S. 599 (1975).

19 Id. at 609 .

${ }^{\text {so }}$ Id. at $610 \mathrm{n} .8$. 
preme Court's decision in Kern-Limerick, Inc. $v$. Scurlock, ${ }^{51}$ the court must also determine whether a contract between the government and a private party alters the normal pattern of statutory incidence. In Kern-Limerick, a government contractor claimed immunity from an Arkansas sales tax on purchases made by him in order to perform a cost-plus-fixed-fee sales contract. The Kern-Limerick Court held collection of the tax unconstitutional, distinguishing the nearly identical case of King \& Boozer by reference to the terms of the contract. Since the Kern-Limerick contract designated the contractor as the government's agent for the purposes of the purchase, and the government was therefore directly obligated to the vendor (although payment was made only through the contractor), the Court found legal incidence of the tax to be on the United States. ${ }^{52}$

The Kern-Limerick doctrine, which permits contractual alteration of the statutory incidence of a tax, allows the government, through careful contract draftsmanship, to restore to private parties the very immunity withdrawn by King \& Boozer. Although the Supreme Court disapproved reliance on "such insubstantial formalities" in upholding a user tax on a government contractor, ${ }^{53}$ the lower federal courts continue to look to contract terms to locate legal incidence. ${ }^{54}$

3. Determination Whether the Taxed Entity is the Government. Once a court has determined on whom the tax is legally incident, it must decide whether that party is entitled to claim the governmental immunity. The answer is not always obvious.

Instrumentalities of the federal government, as well as the government itself, are exempt from legally incident state taxes..$^{55} \mathrm{Al}$ though most federal instrumentalities are easily identifiable, some are not. Generally, a federal instrumentality, for tax immunity pur-

s1 347 U.S. 110 (1954).

52 Id. at 119-121.

${ }_{53}$ United States v. Township of Muskegon, 355 U.S. 484, 486 (1958); see Tribe, Intergovernmental Immunities in Litigation, Taxation and Regulation: Separation of Powers Issues in Controversies A bout Federalism, 89 HARv. L. Rev. 682, 709-10 (1976). But see United States v. Township of Muskegon, 355 U.S. at 489 (Frankfurter, J., concurring).

${ }^{34}$ See, e.g., Federal Reserve Bank v. Commissioner of Claims and Taxes, 500 F.2d 221 (1st Cir. 1975); United States v. Nevada Tax Comm'n, 291 F. Supp. 530 (D. Nev. 1968), aff'd, 439 F.2d 435 (9th Cir. 1971); United States v. Boyd, 211 Tenn. 139, 363 S.W.2d 193 (1962), aff'd on other grounds, 378 U.S. 39 (1963).

ss New Brunswick v. United States, 276 U.S. 547, 555 (1928); United States v. City of Adair, 539 F.2d 1185, 1190 (8th Cir. 1976), cert. denied, 429 U.S. 1121 (1977); United States v. City of Milwaukee, 140 F.2d 286, 288 (7th Cir.), cert. denied, 322 U.S. 735 (1944) (all holding that federal instrumentalities enjoy government status for tax immunity purposes). 
poses, is any entity that performs a federal function without deriving private profit or personal benefit. Agencies of the federal government obviously fulfill both aspects of the test. But a private entity may also achieve the status of a federal instrumentality. In Department of Employment $v$. United States, ${ }^{56}$ the Court held the Red Cross entitled to tax immunity as a federal instrumentality. The Court found controlling significance in the Red Cross's performance of "a wide variety of functions indispensable to the workings of our armed forces . . . to assist the Federal Government in providing disaster assistance to the United States in time of need . . . and . . . reliance upon the Red Cross's status virtually as an arm of the Government" by the President and Congress. ${ }^{57}$ The lower court decision in United States $v$. Livingston, ${ }^{58}$ affirmed by the Supreme Court, ${ }^{59}$ also recognized a private contractor's right to governmental tax immunity. DuPont had agreed to develop, construct, and operate a defense plant without charge to the government, and the majority found the requisite federal function and lack of personal benefit. ${ }^{60}$

Remuneration for performance of a federal function normally prevents conferral of federal instrumentality status on a private entity. In 1967 the Supreme Judicial Court of Massachusetts applied this principle in First Agricultural National Bank v. State Tax Commission $^{61}$ to hold that national banks were not immune from taxes as federal instrumentalities. The Supreme Court reversed, finding that the Congressional grant of tax immunity mooted the issue of whether national banks were federal instrumentalities for purposes of tax immunity doctrine. ${ }^{62}$ The Court has not yet resolved whether an entity operated for private gain can be a federal instrumentality for tax immunity purposes, but recent Supreme Court decisions suggest that the reaping of private profit is inconsistent with governmental status. ${ }^{63}$

4. Taxes Not Legally Incident on the Government. A tax that is not legally incident on the government can run afoul of federal

36 U.S. 355 (1966).

57 Id. at $359-60$.

ss 179 F. Supp. 9 (E.D.S.C. 1959), aff'd mem., 364 U.S. 281 (1960).

364 U.S. 281 (1960).

179 F. Supp. at 22-24.

"1 353 Mass. 172, 299 N.E.2d 245 (1967), rev'd, 392 U.S. 339 (1968).

12392 U.S. 339,341 (1968).

- United States v. County of Fresno, 429 U.S. 452 (1977); McClanahan v. Arizona State Tax Comm'n, 411 U.S. 164 (1973); Mescalero Apache Tribe v. Jones, 411 U.S. 145 (1973); First Agr. Nat'l Bank v. State Tax Comm'n, 392 U.S. 339 (1968) (Marshall, J., dissenting); United States v. Township of Muskegon, 355 U.S. 484, 486 (1958). 
tax immunity doctrine if it discriminates against the federal government. For example, a gross receipts tax that is levied only upon the receipts of contractors doing business with the federal government could not survive judicial scrutiny.$^{64}$ In general, the courts will scrutinize the challenged tax scheme to determine whether the tax falls with greater impact on persons dealing with the government than on persons similarly situated who transact no business with the government. This does not mean, however, that the courts brook no differences in treatment whatsoever. The cases permit a state to exempt a narrow class of private organizations, such as charities, from taxes that economically burden government activities. ${ }^{65}$ The cases have also permitted states to equalize the tax burdens on privately held property and tax-exempt government property by imposing on users of government property taxes that do not reach users of private non-exempt property. ${ }^{66}$ The courts, however, have not tolerated disparate treatment of state governmental entities and federal entities: a tax that burdens federal operations must equally apply to or burden state operations ${ }^{67}$ Finally, the cases suggest that the nondiscrimination standard is supplemented by residual noninterference scrutiny. ${ }^{68}$ As yet, however, no court appears to have invalidated a nondiscriminatory state tax on the grounds that it substantially interferes with federal operations.

5. Summary. The law of federal tax immunity has yet to break free of the formalism entailed by the absolute immunity doctrine of McCulloch and Weston. The concept of legal incidence defines an area within which state taxation is absolutely prohibited.

4 See United States v. Montana, 437 F. Supp. 354 (D. Mont. 1977), cert. granted, 46 U.S.L.W. 3719 (U.S. May 22, 1978).

ss E.g., United States v. Department of Revenue, 202 F.Supp. 757 (N.D. Ill.), aff'd per curiam, 371 U.S. 21 (1962).

s E.g., United States v. County of Fresno, 429 U.S. 452 (1977); United States v. City of Detroit, 355 U.S. 466,473 (1955).

${ }^{87}$ E.g., Moses Lake Homes, Inc. v. Grant County, 365 U.S. 744 (1961); Phillips Chem. Co. v. Dumas Independent School Dist., 361 U.S. 376 (1959). For criticism of this rule see text and notes at notes $178-185$ infra.

os This aspect of the standard is rarely clearly articulated because the situation has not yet arisen in which an indirect tax was found unduly burdensome. Decisions generally do, however, investigate the degree of interference, indicating that undue interference would be a ground for invalidation if presented. See, e.g., United States v. County of Fresno, 429 U.S. 452 (1977). Finding that the incidence of the tax was not on the government, the Court in Fresno concluded:

The tax threatens to interfere with federal law relating to the functions of the Forest

Service only insofar as it may impose an economic burden. . . . There is no other respect in which the tax involved threatens to obstruct or burden a federal function. The tax can be invalidated, then, only if it discriminates against the Forest Service or other federal employees.

Id. at 464 (emphasis in original). 
Taxes that economically burden government operations but whose legal incidence is on those selling goods and services to the government are generally permitted, provided they do not discriminate against or severely burden the federal government. Taxes legally incident on government instrumentalities are forbidden. It is not easy to see the rationale for drawing the line where the doctrine draws it, and a survey of the doctrine's intricacies reveals that objectively like cases may be treated differently, depending on judicial divination of the state legislature's "intent" in imposing the tax. ${ }^{69}$ In large measure the doctrine represents a constriction of federal tax immunity; under the doctrine most federal contractors and forprofit franchises no longer enjoy immunity from state taxation, as they often did under the Weston doctrine. ${ }^{70}$ In general, this pulling back of the tax immunity line fulfills the Dravo Court's desire to leave a broader scope for sovereign powers of taxation. ${ }^{71}$ But the nondiscrimination/noninterference standard adopted in Dravo does not apply to taxation of federal instrumentalities. The per se prohibition of taxes legally incident on federal instrumentalities is the last vestige of Weston.

\section{The Rejection of Absolute Immunities in Related Areas}

At one time direct state taxation of interstate commerce, and of exports and imports, and federal taxation legally incident on state operations were absolutely prohibited as well. The absolute prohibitions in these three areas, as in the federal tax immunity area, gave rise to very formalistic doctrine. Where immunities are theoretically absolute, the zone of absolute prohibition must be demarcated; doctrine must define the impermissible objects of state taxation. Absolute immunity doctrine, in all three areas, tended to draw distinctions that bore little relationship to the purposes behind the immunity in question. In the 1930s the Dravo Court revolutionized federal immunity law in response to the growing gap between federal immunity law and its purposes. In recent years the Supreme Court has similarly revolutionized immunity law in the three areas of state taxation of exports-imports, state taxation of interstate commerce, and federal taxation of state governments. In these areas the Court seems to be abandoning the absolute prohibition approach and the formalism it entails and accommodating sovereign taxing powers with important countervailing interests through

\footnotetext{
See text and notes at notes 48.50 supra.

${ }^{70}$ See text and notes at notes 26-29 supra.

7 See text at note 33 supra.
} 
standards rooted in the policies behind constitutional limitations on the taxing power.

\section{A. Federal Taxation of State Instrumentalities}

Because it has been said that intergovernmental tax immunities should be reciprocal, ${ }^{72}$ the evolution of state immunity from federal taxation is especially pertinent to the examination of federal tax immunity. At present, intergovernmental immunities are not reciprocal, even though both federal and state immunities were originally absolute, at least in theory. The doctrine of state immunity from federal taxation traces a route from the pronouncement in the late nineteenth century of a doctrine of absolute immunity to the Supreme Court's adoption of a functional approach that would immunize the states only from discriminatory taxation and from taxation that unduly interferes with vital state operations. ${ }^{73}$

The immunity of state operations from federal taxation originated with the Supreme Court's decision in Collector v. Day. ${ }^{74}$ In Day, the Court found implicit in the constitutional scheme an absolute immunity of state functions from federal taxation. A series of Court decisions in the seventy years following Day encountered the familiar problem of defining the parameters of the absolute prohibition. The opinions attempted to define the forbidden zone by reference to the character of the state function burdened by federal taxation. ${ }^{75}$ Generally, taxes on "governmental activities" were forbidden, but taxes on "proprietary activities" were not. ${ }^{76}$

72 See Justice Frankfurter's discussion of the origins of state tax immunity in New York v. United States, 326 U.S. 572, 576-77 (1946). In that case Frankfurter criticized the reciprocality argument for ignoring that the states, due to their representation in Congress, have less need than the federal government for the protections of a tax immunity. Reciprocality does not seem to be especially desirable, but not for the reasons given by Justice Frankfurter. The states, one would think, need tax immunity more than the federal government does, for they lack the federal government's self-immunizing power. Recognizing the frailty of the protections afforded the states by their representation in Congress, the Court has recently fortified state regulatory immunity. See National League of Cities v. Usery, 426 U.S. 833 (1976), discussed in text at notes 85-88 infra.

${ }_{73}$ New York v. United States, 326 U.S. 572 (1946). This approach to state tax immunity was recently reaffirmed by Justice Brennan's plurality opinion in Massachusetts v. United States, 98 S.Ct. 1153 (1978).

78 U.S. (11 Wall.) 113 (1871).

75 The history is recounted in Justice Brennan's opinion in Massachusetts v. United States, 98 S. Ct. 1153 (1978).

76 E.g., Helvering v. Powers, 293 U.S. 214, 227 (1934); Ohio v. Helvering, 292 U.S. 360 (1934); South Carolina v. United States, 199 U.S. 437, 454-63 (1905). In Ohio v. Helvering, the Court explained the distinction as follows: "When a state enters the market place seeking customers it divests itself of its quasi sovereignty pro tanto, and takes on the character of a trader, so far, at least, as the taxing power of the federal government is concerned." 292 U.S. at 369. 
The governmental/proprietary distinction was rejected by the Court in its 1946 decision in New York $v$. United States, ${ }^{77}$ in which it upheld a federal tax on the bottling and selling of mineral water by the State of New York. Justice Frankfurter announced the judgment of the Court in an opinion joined by only one other Justice. He reviewed the history of state immunity doctrine, and noted the "whole tendency of recent cases reveals a shift in emphasis to that of limitation upon immunity."78 The recent cases, he claimed, were moving away from reliance on the governmental/proprietary distinction, and were instead trying to restrict the benefits of tax immunity to governmental functions that must be immune "in order to safeguard the necessary independence of the State."79 The purposes of state tax immunity can be fulfilled, said Justice Frankfurter, without "devising doctrines sufficiently comprehensive in detail to cover the remotest contingency."80 The independence of the states is sufficiently protected by a rule forbidding discriminatory federal taxation: "[S]o long as Congress generally taps a source of revenue by whomsoever earned and not uniquely capable of being earned only by a State, the Constitution . . . does not forbid it merely because its incidence falls also in a State."81

Chief Justice Stone, in a concurrence joined by three other Justices, embraced the nondiscrimination standard, but argued that the nondiscrimination principle, without more, would be underprotective of state interests. Some nondiscriminatory taxes legally incident on a state could "nevertheless impair the sovereign status of the state." 82 In Chief Justice Stone's opinion, impairment of sovereign status would be presumed in the case of federal taxes on the most sovereignty-symbolic state operations, such as taxes on the state capitol, on public parks, or on tax and school land revenues. These taxes would be barred without regard to their actual effects even if laid in a nondiscriminatory fashion. ${ }^{83}$

${ }^{77} 326$ U.S. 572 (1946).

${ }^{7 \pi}$ Id. at 581 .

7d. at 580 (quoting Helvering v. Powers, 293 U.S. 214, 227 (1934)).

326 U.S. at 583.

s! Id. at 582 .

$\therefore$ Id. at 583 .

${ }^{83}$ Id. at 587-88. The differences between Frankfurter and Stone on this point are fine indeed. Justice Frankfurter noted that taxation could not extend to taxation of a statehouse or of

state-owned property that partake of uniqueness from the point of view of intergovernmental relations. These inherently constitute a class by themselves. . . . These could not be included for purposes of federal taxation in any abstract category of taxpayers without taxing the State as a State. But so long as Congress generally taps a source of revenue by whomsoever earned and not uniquely capable of being earned only by a state, 
The lower courts, following the ambiguous mandate of New York $v$. United States, have tested federal taxes legally incident on state "governmental" activities under both the Frankfurter and Stone standards. ${ }^{84}$ To date, it appears that no nondiscriminatory federal tax has been invalidated for impermissible interference with state operations.

After thirty years of silence, the Supreme Court imported even further uncertainty into the already imprecise equation in its opinion in National League of Cities $v$. Usery ${ }^{85}$ In National League of Cities the Court invalidated the 1974 Fair Labor Standards Act amendments that required the states to pay minimum wage to all state employees. The question presented was state immunity from federal commerce clause regulation, not state immunity from federal taxation. In prior cases, the Court had decided unequivocally that the constitutional limitations imposed on taxation of the states were inapplicable to regulation of the states..$^{88}$ Disregarding precedent, Justice Rehnquist, writing for the majority in National League of Cities, invoked Chief Justice Stone's opinion in New York $v$. United States to invalidate the challenged regulation of the states, ${ }^{87}$ finding that the distinction between regulatory and tax immunities "escapes us".88

The import of the Court's reasoning is that National League of

the Constitution of the United States does not forbid it merely because its incidence falls also on a state.

Id. at 582. Chief Justice Stone's catalogue of impermissible objects of federal taxation seems broader than Justice Frankfurter's, but the scope of Frankfurter's class of state property unique "from the point of view of intergovernmental relations" is unclear to say the least. If he thought that he was adumbrating a class of property that could be taxed only in a discriminatory fashion, Justice Frankfurter was probably wrong. It is hard to see how a federal tax levied against a statehouse but which reached all such property within the state could be called discriminatory. The compulsion of both justices to make an effort to define an absolutely protected zone suggests that the Court had not yet broken free of the tendency to ignore what Frankfurter, speaking of $\mathrm{McC}$ Culloch, called "the practical limitations of a rhetorical absolute." Id. at 576. The tenor of the opinions in this respect differs sharply from that of Justice Brennan's opinion in the Massachusetts case, discussed in the text at notes 94-100 infra.

st See, e.g., City of New York v. United States, 394 F. Supp. 641 (S.D.N.Y. 1975), aff'd mem., 538 F.2d 308 (2d Cir. 1976); United States v. Washington Toll Bridge Authority, 307 F.2d 330 (9th Cir. 1962), cert. denied, 372 U.S. 911 (1963).

\&s 426 U.S. 833 (1976).

" Maryland v. Wirtz, 392 U.S. 183 (1968); United States v. California, 297 U.S. 175, 184 (1936) (rejecting the tax immunity doctrine as "not illuminating" to the problem of commerce clause regulation). See also McCormack, Intergovernmental Immunity and the 11th Amendment, 51 N.C.L. REv. 485, 496-97 (1973). See, however, Justice Frankfurter's use of United States v. California as precedent in New York v. United States, 326 U.S. 572, 582 (1946).

${ }^{\mathrm{x}} 426$ U.S. at 843 \& n.14.

\& Id. But see Justice Brennan's dissenting opinion, finding the majority's reliance on New York misplaced. Id. at 863-64. 
Cities's commerce clause standard will be relevant to suits challenging federal taxation of state instrumentalities. Since application of that standard in National League of Cities resulted in the invalidation of federal regulation, it might seem that the decision also portends an expansion of state immunity from federal taxation. Proper regard to the differential effects of regulation and taxation, however, suggests that state tax immunity should not be expanded as a consequence of National League of Cities. The focus of the Rehnquist and Stone standards is essentially the same. Under National League of Cities, Congressional regulation must not interfere with "functions essential to "separate and independent existence," "integral governmental functions." Application of that standard to federal regulation is far more likely to result in invalidation than is application of the identical standard to taxation because regulation, even when nondiscriminatory, is far more likely to interfere with sovereign functions than nondiscriminatory taxation. ${ }^{91}$ The Court in National League of Cities concluded that "insofar as the challenged amendments operate to directly displace the states' freedom to structure integral operations in areas of traditional governmental functions, they are not within the authority granted Congress by art. I, $\S 8 \mathrm{cl}$. 3." "This "direct displacement" of state decisionmaking is generally not attendant to nondiscriminatory taxation. Nondiscriminatory taxation could rarely operate to directly preclude state choices. It only requires that added costs be taken into account in the decision-making process. Justice Rehnquist, the author of the majority opinion in National League of Cities, expressed the point in an earlier opinion:

Where the Federal Government seeks only revenue from the State, the State may provide the revenue and make up the difference where it chooses among its sources of revenue or demands for expenditure. But where the Federal Government seeks not merely to collect revenue as such, but to require the state to pay out its moneys to individuals at particular rates, not merely state revenues but also state policy choices suffer. ${ }^{93}$

Id. at 845 (quoting Coyle v. Smith, 221 U.S. 559, 565 (1911)).

426 U.S. at 851.

"See McCormack, supra note 86, at 494; Powell, The Waning of Intergovernmental Tax Immunities, 58 Harv. L. REv. 633, 645-66, nn. 83 \& 84 (1945). The decisions in the field of federal immunity from state regulation frequently invalidate state laws for impermissible interference with federal functions, even when the regulation is not directly incident on those functions. Tribe, supra note 53, at 703. In sharp contrast, no decision assessing the impact of nondiscriminatory taxation, whether state or federal, has found impermissible interference.

92426 U.S. at 852.

" Fry v. United States, 421 U.S. 542, 554 (1975) (dissenting opinion). 
That Chief Justice Stone's approach to state tax immunity questions survives National League of Cities is evidenced by the Court's recent decision in Massachusetts $v$. United States. ${ }^{94}$ The Massachusetts decision upheld a federal user charge on state-owned aircraft, a form of levy that one lower court had earlier invalidated in reliance on National League of Cities. ${ }^{945}$ Justice Brennan wrote for a Court majority upholding the charge. The section of his opinion dealing with the tax immunity issue, which attracted only a plurality, augurs a further diminution of state tax immunity. Justice Brennan characterized Chief Justice Stone's New York opinion as a majority opinion, ${ }^{96}$ and carried Stone's "practical construction"97 a step further. Although noting that "the Court has by no means abandoned its doubts concerning its ability to make particularized assessments of the impact of revenue measures in essential state operations," ${ }^{98}$ Justice Brennan set forth a functional test: "Where the subject of tax is a natural and traditional source of federal revenue and where it is inconceivable that such a revenue measure could ever operate to preclude traditional state activities, the tax would be valid." J99 Justice Brennan's choice of the term "preclude" is particularly significant. It is difficult to imagine any federal taxation effort that would be barred by this formulation, unless the "natural and traditional source" branch of the test is intended to refer to an unspecified core of state activities that have not heretofore been subjected to federal taxation, a category similar to Stone's category of sovereignty-symbolic objects. Although Justice Brennan lacked the support of a majority of the eight Justices on this point, ${ }^{100}$ his formulation demonstrates how far the debate has

9498 S. Ct. 1153 (1978),

${ }^{25}$ State Dep't of Transp. v. United States, 430 F. Supp. 823 (N.D. Ga. 1976). The Georgia district court read National League of Cities as overruling New York v. United States, 430 F. Supp. at $824 \mathrm{n} .1$, and as requiring the invalidation of federal taxation of "entities through which a state carries forward its essential and traditional governmental functions." Id. at 826. Massachusetts was not a direct appeal from the Georgia case, but the Court upheld the precise tax invalidated by the Georgia district court.

s Since Justice Frankfurter's opinion in New York upheld the tax on a ground broader than that taken by Chief Justice Stone's concurrence, which was joined by three other justices, Justice Brennan concluded that "a majority supported the Chief Justice's rationale." 98 S. Ct. at 1162 n.15.

${ }^{97}$ Id. at 1163.

2x Id.

s? Id.

${ }^{100}$ Justices Stewart and Powell declined to join Justice Brennan's discussion of the immunity issue. They pointed out that the parties conceded that "a nondiscriminatory user fee may constitutionally be imposed upon a state," $i d$. at 1169 , but cited no cases on state 
come since the Court announced an absolute immunity doctrine in the Day case.

B. State Taxation of Interstate Commerce and of Imports and Exports.

Just as it did in the area of federal taxation of state instrumentalities, the Court in the past two years has rejected absolute immunity theory in favor of functionalism in the areas of commerce clause and import-export clause limitations on state taxing power. In both areas the Court has discarded old doctrines that forbade the states from directly taxing the objects protected by specific constitutional provisions. ${ }^{101}$

1. Interstate Commerce. In the recent case of Complete Auto Transit, Inc. $v$. Brady, ${ }^{102}$ the Supreme Court abandoned a thirtyyear-old doctrine that banned state taxation levied "directly" upon interstate commerce.

The doctrine reconsidered in Complete Auto Transit was first announced in the 1946 case of Freeman v. Hewit. ${ }^{103}$ Freeman involved a challenge to an attempt by the state of Indiana to impose its gross income tax on the income generated by an Indiana trustee's sale of securities on the New York Stock Exchange. The Court struck down the tax as violative of the limitations imposed by the commerce clause. ${ }^{104}$ Writing for the majority, Justice Frankfurter stated that the commerce clause "does not merely forbid a state to single out interstate commerce for hostile action. A state is also precluded from taking any action which may fairly be deemed to

tax immunity for the proposition. The concurring opinion conveys the impression that the constitutionality of imposing nondiscriminatory user taxes on state instrumentalities has been long settled. It has long been the law that state user fees and beneficial assessments upon parties engaged in interstate commerce are not prohibited by the commerce clause. E.g., Evansville-Vanderburgh Airport Auth. Dist. v. Delta Airlines, Inc., 405 U.S. 702 (1972); Clyde Mallory Lines v. Alabama, 296 U.S. 261 (1935). But the beneficial nature of a challenged assessment against federal instrumentalities ordinarily fails to save the assessment from invalidation. See United States v. City of Adair, 539 F.2d 1185 (8th Cir. 1976), cert. denied, 429 U.S. 1121 (1977); Board of Directors v. Reconstruction Fin. Corp., 170 F.2d 430 (8th Cir. 1948). But see Swords v. Nutt, 11 F.2d 936 (9th Cir. 1926) (holding national bank not immune from local beneficial assessments).

Prior to the Massachusetts case the Court had not faced the question of state immunity from federal user charges. Although several of the precedents invoked by Justice Brennan rested on the theory that a user fee is not a tax, e.g., Clyde Mallory Lines v. Alabama, 296 U.S. 261 (1935), Justice Brennan's opinion in Massachusetts seemed to avoid that rationale. 101 See generally Hellerstein, State Taxation and the Supreme Court: Toward a More Unified Approach to Constitutional Adjudication? 75 Mich. L. Rev. 1426 (1977).

102430 U.S. 274 (1977).

123 329 U.S. 249 (1946).

104 U.S. ConST., art. I, $\S 8$, cl. 3. 
have the effect of impeding the free flow of trade between states." 105 Rather than examine the tax in question to determine whether it could in fact impede the free flow of trade, however, Justice Frankfurter declared the tax unconstitutional because it fell directly on "the very process of interstate commerce."106 Justice Rutledge's lamentation, in dissent, that "[j]udgments of this character and magnitude cannot be made by labels or formulae" 107 is an apt comment upon the jurisprudence that flowed from the Court's subsequent efforts to give meaning to Justice Frankfurter's distinction between direct and indirect taxation of interstate commerce. ${ }^{108}$ The doctrine reached the height of formalism when a Virginia gross receipts tax, declared unconstitutional by the Court at a time when the taxing statute characterized the tax as a tax on the privilege of doing business in the state, ${ }^{109}$ was upheld by the Court after the Virginia legislature had stricken the offending phrase. ${ }^{110}$

In Complete Auto Transit, Inc. v. Brady'11 a unanimous Court abandoned the direct incidence rule. The incidence rule, said the Court, "has been stripped of any practical significance." 112 The question under the commerce clause is whether the tax produces " $a$ forbidden effect," and the rule of incidence, the Court concluded, is irrelevant to that determination. ${ }^{113}$ So long as the activity taxed is "sufficiently connected to the State," the state can constitutionally levy a nondiscriminatory, fairly apportioned tax that bears a fair relationship to the benefits provided the taxpayer. ${ }^{114}$

2. Import-Export Clause. In the case of Michelin Tire Corp. $v$. Wages, ${ }^{115}$ the Supreme Court rejected a mechanical approach to testing the validity under the import-export clause ${ }^{116}$ of state taxation of imported goods that have come to rest in the state. Importexport clause inquiry, before the Michelin case, focused on whether challenged state taxes fell on imported goods that still retained their character as imports. In the 1872 case of Low v. Austin ${ }^{117}$ the Court

105329 U.S. at 252.

ios Id. at 253 .

lor Id. at 270.

${ }^{108}$ The history of the Court's efforts to grapple with the distinction erected in Freeman v. Hewit is recounted in Complete Auto Transit, Inc. v. Brady, 430 U.S. 274, 279-87 (1977).

109 Railway Express Agency v. Virginia, 347 U.S. 359 (1954) (Railway Express I).

"10 Railway Express Agency v. Virginia, 358 U.S. 434 (1959) (Railway Express II).

III 430 U.S. 274 (1977).

"12 Id. at 288.

${ }^{13}$ Id.

iss Id. at 287.

11s 423 U.S. 276 (1976).

II' U.S. Const. art. I, § 10, cl. 2.

${ }^{117} 81$ U.S. (13 Wall.) 29 (1872). 
held that even non-discriminatory ad valorem taxes on imported goods are impermissible unless the goods have lost their character as imports.

The Michelin Court, finding nothing in the history of the import-export clause that demanded the rule of Low v. Austin, overruled that decision. The Framers, according to the Court, forbade the states to lay imposts and duties on imports for three main reasons: first, in order to preserve to the federal government the exclusive regulation of foreign commerce; second, to prevent the states from siphoning off import revenues, which the Framers thought would be an important source of federal revenue; and third, to forestall the frictions that might arise were the seaboard states to tax citizens of the land-bound states for the privilege of using their ports. ${ }^{118}$ Nondiscriminatory property taxes, the Court pointed out, pose no threat to any of the policies of the clause. They cannot, by definition, "fall on imports as such because of their place of origin"119 nor can they be applied selectively to discourage importation. ${ }^{120}$ The economic burden of such taxes will affect federal import duties only to the extent they discourage the purchase of imported goods. ${ }^{121}$ Finally, nondiscriminatory taxes cannot unduly interfere with the "free flow of imported goods among the states, as did the exactions by states under the Articles of Confederation directed solely at imported goods." ${ }^{22}$ As in Complete Auto Transit, the Court rejected venerable doctrine that determined the validity of a tax by reference to its objects, and not, as the reasons for the taxing power limitation would demand, by reference to its predictable effects. ${ }^{123}$

i1s 423 U.S. at $285-86$.

i" Id. at 286.

120 Id.

${ }^{121}$ Id. at $286-87$.

122 Id. at 288 .

${ }^{123}$ In its most recent decision on the import-export clause, Department of Revenue v. Association of Wash. Stevedoring Cos., 98 S. Ct. 1388 (1978), the Court unanimously upheld the application of Washington's business and occupation tax to companies engaged in handling goods passing in foreign commerce. The case differed from Michelin in that it involved goods that were in transit. Because the Court was able to uphold the tax without departing from existing precedent concerning the legality of taxes on goods in transit, it did not rest the decision on the functional Michelin test. Justice Powell, in concurrence, expressed mystification that the Court would attach significance to the fact that the case involved goods in transit and accused the Court of returning to formalism. Id. at 1405-06 (Powell, J., concurring). The majority responded that it preferred "to defer decision until a case with pertinent facts is presented. At that time, with full argument, the issue with all its ramifications may be decided." Id. at $1403 \mathrm{n} .23$. Although the Court refused to rely on the Michelin approach, the majority remarked at the end of its opinion that "distinctions not based on differences in constitutional policy are not required." Id. at 1405 . 


\section{Evaluation of the Legal Incidence Rule}

The legal incidence rule of federal immunity from state taxation, which absolutely prohibits direct state taxation of federal instrumentalities, has become an odd corner in the constitutional law of limitations on sovereign taxing power. Nowhere else in the law, as demonstrated above, does the validity of taxation seem to turn to so great an extent on the mere form of the taxation in question. Thirty-four years ago, Learned Hand commented that were he "free to start afresh," he would abandon the legal incidence doctrine as a "barren way to treat the distribution of power" in the federal system. ${ }^{124}$ Recent developments in related areas of the law make it possible, indeed appropriate, to consider starting afresh. ${ }^{125}$ The Supreme Court's shift, represented by Michelin and Complete Auto Transit, from an absolutist to a purposive approach to constitutional tax immunity questions suggests the need to reexamine the rule's absolute prohibition of direct taxation of federal instrumentalities.

Indeed, reexamination of federal tax immunity seems all the more urgent in view of the Court's tendency to reason across the various areas of constitutional tax immunity. In determining the constitutionality of the federal user charge challenged in the Massachusetts case, the Court relied partly on caselaw in the field of interstate commerce immunity, finding that "decisions . . . interpreting provisions in the Constitution that also place limitations on the taxing power of government" are "clearly analogous". ${ }^{26}$ Even more revealing, however, is the Supreme Court's reasoning in the now-overruled interstate commerce immunity decision in Spector Motor Service, Inc. v. O'Connor. ${ }^{127}$ The Spector Court cited federal tax immunity decisions to justify its adherence to a rule of legal incidence in the area of interstate commerce taxation. Retention of legal incidence in that area was said to give "lateral support to one of the cornerstones of our constitutional law-McCulloch v. Mary-

${ }^{124}$ Spector Motor Serv., Inc. v. Walsh, 139 F.2d 809, 822 (2d Cir. 1943) (dissenting opinion), rev'd, 323 U.S. 101 (1944).

${ }^{125}$ In fact, Hand's opinion in Walsh leaves no doubt that the Supreme Court's recent decision in Complete Auto Transit would have been precisely the authority needed to "start afresh." The majority in Walsh upheld a nondiscriminatory tax levied directly on interstate commerce. Judge Hand dissented, not because of a disagreement with the merits of the majority's position, but because he believed the Supreme Court decisions retaining legal incidence in the federal tax immunity area required adherence to legal incidence in the area of interstate commerce as well. Id. at 823.

12598 S. Ct. 1153,1164 (1978).

127340 U.S. 602 (1951). 
land. "I28 Lateral support for the doctrine of federal immunity from state taxation was withdrawn by the Supreme Court not only in Complete Auto Transit, but in Michelin as well. ${ }^{129}$ The doctrine's vitality should depend on how well it fits the policy foundations for a judicial doctrine of federal tax immunity.

\section{A. Goals of a Tax Immunity Doctrine}

1. Accommodating State and Federal Interests. The purpose of intergovernmental tax immunities is to prevent one sovereign from interfering with the governmental functions of another. Any sound judicial doctrine of immunities must assure this, but it must also take into account countervailing state interests.

The state interest abridged by federal tax immunity is a fundamental one. Our constitutional system is designed to leave the broadest feasible scope for state taxation powers. Hamilton was of the opinion that the Constitution preserves to the states "absolute and unqualified" taxing powers, subject to the "sole exception of duties on imports and exports." 130 Moreover, it is not only constitutional principles that argue for minimal incursion upon state powers of taxation. Courts have recognized the force of equitable considerations as well: it is only fair and proper that the beneficiaries of state services pay the taxes necessary to support those services. ${ }^{131}$ The federal judiciary, accordingly, has zealously guarded the states' power to tax. In the Michelin case, the Supreme Court announced that the states' power to tax can be denied "only under the clearest constitutional mandate." 132

$12 \pi$ Id. at 610 .

120 In Brown v. Maryland, 25 U.S. (12 Wheat.) 419, 430-40 (1827), John Marshall employed $\mathrm{McCulloch}$-styled reasoning to deny the states any constitutional power to tax imports and exports. Although the Michelin court reinterpreted Brown as prohibiting only nondiscriminatory taxation of imports and did not directly overrule it, the Court nonetheless rejected the absolutist approach and narrowly restructured the doctrine to fit the purposes of the import-export clause.

${ }^{130}$ The Federalist No. 32 (A. Hamilton). With the single exception of the import-export clause, the Constitution is silent about state taxing powers; the powers are "absolute" by negative implication.

I3t Michelin Tire Corp. v. Wages, 423 U.S. 276 (1976). Concerning the state power to tax imports, the Court noted: "There is no reason why local taxpayers should subsidize the services used by the importer; ultimate consumers should pay for such services as police and fire protection accorded the goods just as much as they should pay transportation costs associated with those goods." 423 U.S. at 289. See also the Court's reasoning in Complete Auto Transit, Inc. v. Brady, 430 U.S. 274, 289 n.15 (1977), that the administrative convenience of absolute immunities is "insufficient justification for abandoning the principle that 'interstate commerce may be made to pay its way.' "See also Panhandle Oil Co. v. Mississippi ex rel. Knox, 277 U.S. 218, 222 (1927) (Holmes, J., dissenting).

132 Michelin Tire Corp. v. Wages, 423 U.S. 276, 293 (1976). 
Recognition of an immunity necessarily restricts a state's taxing power. Any doctrine of intergovernmental tax immunity represents a balance between one sovereign's power to tax and the taxed sovereign's need for the immunity. ${ }^{133}$ Indeed, the evolution of federal tax immunity doctrine is perhaps best understood if immunity doctrine is viewed as the effort to adequately protect federal sovereignty in the manner least restrictive of state taxing powers. The $\mathrm{McC}$ Clloch-Weston doctrine, which absolutely prohibited any state tax that burdened federal operations, might not appear to strike an even balance. Yet, given the political and economic milieu in which those cases arose, no other balance, in John Marshall's estimation, could have been struck. In Marshall's view, the only reliable means of safeguarding one sovereign from the possibly destructive powers of another was legislative representation. ${ }^{134}$ Without representation in state governments, the as-yet weak federal government of Marshall's day needed the protection of an absolute immunity. ${ }^{135}$

The cutback in federal immunity that began with the rejection, in the Dravo case, of the property/operations distinction, is not

133 In Metcalf \& Eddy v. Mitchell, 269 U.S. 514 (1926), the Court observed:

[T] he limitation upon the taxing power of each, and so far as it affects the other, must receive a practical construction which permits both to function with the minimum of interference each with the other, and that limitation cannot be so varied and extended as seriously to impair either the taxing power of the government imposing the tax . . . or the appropriate exercise of the functions of the government affected by it.

Id. at 523-24 (citations omitted). Justice Brennan reiterated this point in his opinion in Massachusetts v. United States, 98 S.Ct. 1153 (1978): "When the scope of the States' constitutional immunity is enlarged beyond that necessary to protect the continued ability of the States to deliver traditional government services, the burden of the immunity is thrown upon the National Government without any corresponding promotion of the constitutionally protected values." Id. at 1163.

134 "The only security against the abuse of [the taxing] power, is found in the structure of the government itself." McCulloch v. Maryland, 17 U.S. (4 Wheat.) 316,428 (1819).

135 Judge Learned Hand expressed this in his dissent in Spector Motor Service, Inc. v. Walsh, 139 F.2d 809 (2d Cir. 1944), rev'd, 323 U.S. 101 (1944):

The prevalent doctrine may perhaps be accounted for because in the early days of the Republic it was natural-possibly it was necessary-to set absolute boundaries in the distribution of political power. National sentiment was weak, Congress was not disposed to a strong assertion of federal powers; and it always gives an appearance of greater authority to a conclusion to deduce it dialectically from conceded premises than to confess that it involves the appraisal of conflicting interests, which are necessarily incommensurable ....

Id. at 822-23 (L. Hand, J., dissenting). See also Powell, The Waning of Intergovernmental

Tax Immunities, 58 Harv. L. Rev. 633, 652 (1945). Similarly, Konefsky has remarked:

In a real sense, Marshall's formulation of the immunity doctrine was part of his larger struggle against states rights. It is little wonder, then, that he should have sought legal formulas which would permanently protect the federal government from encroachment on its authority and institutions by the state. The resulting doctrine of tax immunity was a product of this period of anxiety.

KONEFSKY, supra note 18 , at 42. 
wholly inconsistent with $\mathrm{McCulloch}$ and Weston. By the time Dravo was decided, the danger that states would abuse the taxing power had greatly subsided, partly because of major political and social changes, partly because of the emergence of alternative safeguards. In particular, it had become firmly established that the Congress could, by legislation, immunize federal functions from state taxation. ${ }^{136}$ Indeed, the Dravo Court cited this development as a justification for abandoning the economic burden rule. ${ }^{137}$ Thus, despite changes in substantive doctrine, it is accurate to say that judgemade federal tax immunity historically has served mainly to supplement alternative safeguards against state interference with federal functions. Recent decisions explicitly acknowledge the relevance of "political checks . . . to a determination of the proper scope of . . . immunity." 138

2. Institutional Considerations. Two further desiderata of an immunity doctrine flow from institutional limitations of the judiciary. First, the immunity standard, like most judicial doctrines, must be capable of easy application. In McCulloch, Marshall expressed great concern that the courts not become involved in adjudicating federalism issues in an ad hoc fashion. ${ }^{139}$ One purpose of the absolute rule of $\mathrm{McCulloch}$-Weston was to avoid the need for recurrent judicial lawmaking in the field. ${ }^{140}$ Although the Weston rule has been abandoned-perhaps because of its unmanageability-the decisions still emphasize the need for broad standards that avoid enmeshing the courts too deeply in "the perplexing inquiry, so unfit for the judicial department, what degree of taxation . . . may amount to the abuse of power."141

The second goal is related to the first. A judicial immunity doctrine should ensure as far as possible that important questions of state-federal relations are decided by the proper forum. There seems to be general agreement with the view once expressed by Justice Black: "Wise and flexible adjustment of intergovernmental tax immunity calls for political and economic considerations of the greatest difficulty and delicacy. Such complex problems are ones

ise See generally Tribe, supra note 53 , at $700 \&$ n. 82 .

is7 302 U.S. at 161.

I3x Massachusetts v. United States, 98 S. Ct. 1153, 1162 n.13 (1978); United States v. County of Fresno, 429 U.S. 452 (1977).

i3s 17 U.S. (4 Wheat.) at $429-30$.

so Id.

"' Id. 430 (1819). See Massachusetts v. United States, 98 S. Ct., 1153, 1163 (1978): "[T]he Court has by no means abandoned its doubts concerning its ability to make particularized assessments of the impact of revenue measures on essential [government] operations ...." 
which Congress is best qualified to resolve."112 Judicial restraint is especially desirable in the field of federal tax immunity because that immunity is founded not on the Constitution itself, but on the "intent" of Congress. ${ }^{143}$ A well-designed immunity doctrine will performs its protective function in a way that recognizes the limitations of the judiciary qua political institution, and will reserve the major decisions for the legislative branch.

\section{B. Evaluating the Legal Incidence Doctrine.}

1. The Accommodation Struck by the Doctrine. The central function of constitutional tax immunity is to protect the government from interference with its sovereign functions. There is no question that an absolute prohibition against states levying taxes legally incident on the federal government serves to prevent interference. But it also substantially erodes the state tax base. As suggested above, the reach of federal immunity from state taxation should be determined by the adequacy of other safeguards in the political and judicial system to the task of protecting federal interests.

The Court in Michelin rejected almost 150 years of precedent in order to ensure that state taxing power is not deprived without "the clearest constitutional mandate." 144 Examination of the balance struck by the legal incidence rule should begin with the Michelin touchstone. The first thing to be observed is that the absolute prohibition of legally incident taxes contrasts sharply with the noninterference/nondiscrimination standard against which nonlegally incident taxes are measured. There is no reason to believe that the Supreme Court's decisions with respect to indirect-not legally incident-state taxation have ignored any "clear constitu-

${ }^{142}$ United States v. City of Detroit, 355 U.S. 466, 474 (1958); see Massachusetts v. United States, 98 S. Ct. 1153, 1161 (1978); Kern-Limerick, Inc. v. Scurlock, 347 U.S. 110, 122 (1954) ("intergovernmental submission to taxation is primarily a problem of finance and legislation"); Helvering v. Gerhardt, 304 U.S. 405, 411, n.1 (1938). See also Tribe, supra note 53, at 711 , arguing that the current tax immunity doctrine is structured to reserve for Congress the adjustment of "competing fiscal and symbolic claims of federal autonomy and state revenue needs."

${ }^{143}$ The supremacy clause basis of modern federal immunity was once explained by Chief Justice Stone as follows:

Since the acts of Congress within its constitutional power are supreme, the validity of state taxation of federal instrumentalities must depend (a) on the power of Congress to create the instrumentality and (b) its intent to protect it from state taxation. Congress may curtail an immunity which might otherwise be implied . . . or enlarge it beyond the point where, Congress being silent, the court would set its limits.

Helvering.v. Gerhardt, 304 U.S. 405, 411 n.1 (1938) (citations omitted).

14423 U.S. at 293. 
tional mandate," and thus underprotected federal interests. The Court has recently emphasized that a tax cannot be unconstitutional if it "effects no greater interference with . . . sovereignty than do the restrictions which this Court has approved."145 The broad sweep of the legal incidence rule, therefore, is not justified unless legally incident taxes interfere more severely with federal functions than do taxes that are not legally incident on federal instrumentalities, or unless absolute immunity is the only adequate safeguard against the abuses that might ensue were the states free to levy taxes legally incident upon federal instrumentalities. ${ }^{146}$

The most obvious burden imposed by any form of taxation is the economic burden of the tax itself. It cannot be maintained that taxes legally incident on the federal government would always be more economically burdensome to the government than are taxes imposed on its agents. Indeed, the costs to the government of taxes imposed on its agents may often exceed the costs that would result from permitting direct state taxation of federal instrumentalities. ${ }^{147}$ Nonetheless, legal incidence may function in a rough way to bar more burdensome forms of state taxation, in that it represents a line between taxes that are often wholly incident on the government in an economic sense and those taxes that generally have a lesser economic impact on the government. In other words, the government would almost always bear the full cost of a state tax that is legally incident on it, but would usually bear less than the full brunt of a tax legally incident on one of its agents. ${ }^{148}$

This point cannot, however, justify differential treatment of legally incident and non-incident taxation. More specifically, it does not justify absolute prohibition of legally incident taxes. First, the mere economic burden of a state tax does not make it constitutionally infirm. ${ }^{149}$ The Supreme Court in United States $v$. County of Fresno ${ }^{150}$ upheld a tax against constitutional challenge only

is Massachusetts v. United States, 98 S. Ct. 1153, 1164 (1978).

116 The traditional formulation of the supremacy clause test is whether the state law "stands as an obstacle to the accomplishment and execution of the full purpose and objectives of Congress." Hines v. Davidowitz, 312 U.S. 52, 67 (1941).

it See, e.g., United States v. County of Fresno, 429 U.S. 452 (1977).

is In many cases, however, the economic burden of taxes that are not legally incident will fall wholly on the government, either because of the absence of alternative sources of supply or because of government consent under a cost-plus-fixed-fee contract.

'" In United States v. County of Fresno, 429 U.S. 452 (1977), the Court held that "the economic burden on a federal function of a state tax . . . does not render the tax unconstitutional." Id. at 462 . The Court found only a "single arguable departure from this principle since 1937." Id. at 462 n.10. See also United States v. City of Detroit, 355 U.S. 466, 472 (1958); Alabama v. King \& Boozer, 314 U.S. 1, 12 (1941); Graves v. New York ex rel. O'Keefe, 306 U.S. 466, 487 (1939); James v. Dravo Contracting Co., 302 U.S. 134, 160 (1937).

130429 U.S. 452 (1977). 
because the economic burden of the tax would be absorbed by the federal government. ${ }^{151}$ Second, the argument rests on the premise that it is permissible to avoid inquiry into the actual effects of particular state taxes. Justice Frankfurter was once able to say, "That in a particular case there may in fact be no conflict in the exercise of the two governmental powers is not to the point." ${ }^{152}$ But Justice Frankfurter's identical argument in his opinion in Freeman $v$. Hewit, ${ }^{153}$ advocating legal incidence as a governing standard for interstate commerce tax immunity, was specifically rejected in Complete Auto Transit. The Supreme Court made it clear in Michelin as well that state taxing power should only be restricted after particularistic inquiry and not through doctrines that presume comprehensive classes of state taxation too burdensome. The fact that the legal incidence rule operates in a rough way to prohibit the forms of taxation that are likeliest to fall wholly on the federal fisc does not justify it.

Economic burdens aside, the most obvious burdens attendant upon state taxation are administrative burdens. It is true that the federal government would usually, although not always, have to pay legally incident taxes directly to the state rather than to an intermediary third party. ${ }^{154}$ But the administrative costs of direct payment cannot be much greater than the costs imposed by many forms of "indirect" taxation. The case of United States $v$. County of Fresno ${ }^{155}$ provides a good illustration. As a result of the employee-paid tax challenged in that case, the Court recognized, the federal government would probably be forced to compute the amounts of the tax, and to incur the costs of reimbursing its employees, ${ }^{156}$ a burden

151 In County of Fresno, federal employees occupying federal housing were subject to a possessory use tax applicable only to renters of publicly owned, tax exempt housing. Since the employees' rents, payable to the federal government, were equivalent to the fair market value of rents charged for privately owned housing, the added liability for the state housing tax would place an economic burden on federal employees not shared by other California renters. The Court upheld the tax against a charge of discriminatory impact. The tax was not discriminatory, reasoned the Court, because the federal government, in order to remain competitive in the rental or employment markets, would have to reimburse the employees for the added cost. Id. at $464 \&$ n.12. In effect then, the Court concluded that the tax was constitutional because it burdened the federal government. The tax was also not discriminatory against the government since an equivalent tax burden, in the form of real property taxes, was shared by private landlords in the state. Id. at 464-65.

${ }_{152}$ City of Detroit v. Murray Corp. of America, 355 U.S. 489, 504 (1955) (Frankfurter, J., dissenting).

${ }^{153} 329$ US. 249, 252-54 (1946).

154 The federal government would not pay the tax directly to the state in cases where the responsibility for payment and the legal incidence of the tax do not fall on the same party. See Kern-Limerick Inc. v. Scurlock, 347 U.S. 110 (1954).

${ }^{155} 429$ U.S. 452 (1977).

${ }^{135}$ Id. at 464 . 
much greater than the burden that direct payment of the tax would have imposed. The Court did not find this potential administrative burden constitutionally impermissible. ${ }^{157}$ In general, it is difficult to see how legally incident taxation could entail added transaction costs. Unless it is the case that direct taxation generally forces the taxed entity to compute the amount it is required to pay, it does not seem that direct payment to the taxing unit involves significant costs that payment of "indirect taxes" through landlords or contractors does not also entail.

In City of Detroit v. Murray Corp. ${ }^{158}$ Justice Frankfurter identified two other potential burdens peculiar to direct taxation. First, such taxation might result in state attempts to sue the federal government for collection of the tax. It is unclear, however, why it is any more objectionable for the state to attempt to sue the federal government for nonpayment of a tax than it is for a contractor to sue the federal government for failure to reimburse him for payment of a state tax. Certainly the interference-the litigation cost-is the same. And mere avoidance of federal-state confrontation in the courts is a poor rationale since that very confrontation is permitted when the federal government sues the state for nonpayment of a tax. A second point raised by Justice Frankfurter is the spectre of state efforts to seize federal property for nonpayment of legally incident taxes. ${ }^{159}$ This problem appears more imagined than real, however, because such efforts, should they ever ensue, would be thwarted by federal regulatory immunities. ${ }^{160}$ Moreover, the mere possibility of state coercive action has long been held insufficient interference to justify prohibition of state taxation. ${ }^{161}$

Thus it appears that legally incident taxes do not impose significantly greater burdens on the federal government than do taxes economically but not legally incident on the government. The only question remaining is whether absolute immunity from legally incident taxes is necessary because of the absence of alternative safeguards. The answer is that there are no safeguards against the burdens imposed by taxes not legally incident that do not equally safeguard the federal government from the potential interference of legally incident taxation. The most obvious safeguard is the Congress,

157 Id. But see Justice Stevens's conclusion that the potential administrative burden was one ground for invalidation of the tax. Id. at $470 \mathrm{n} .5$ (dissenting opinion).

138 355 U.S. 489 (1955).

is9 Id. at 505 .

${ }^{160}$ Mayo v. United States, 319 U.S. 441 (1943); see Tribe, supra note 46, at 704.

${ }^{161}$ City of Detroit v. Murray Corp. of America, 355 U.S. 489, 492 (1958); S.R.A. Inc. v. Minnesota, 327 U.S. 558 (1946). See also Tribe, supra note 53, at 704-05 \& n.102. 
which can immunize federal instrumentalities from any unduly burdensome state tax. If a state enacted legislation subjecting the liquor purchases of the United States to a sales tax, Congress could, if it wished, immunize the purchases even before the statute's effective date. In addition, abandonment of legal incidence need not mean abandonment of all efforts to judicially police the exercise of state taxation powers. The courts could test legally incident taxation against the nondiscrimination/noninterference standards currently applied to taxation that is not legally incident. ${ }^{162}$ Since legally incident taxes generally impose no special burdens, and since there exist safeguards against the abuse of "direct" taxation, the legal incidence rule must be judged overbroad in the Michelin sense.

2. Institutional Considerations. The legal incidence doctrine of federal tax immunity law does not fulfill John Marshall's ideal of administrability. As shown earlier, the doctrine has intricacies which, although less forbidding than those of pre-Dravo doctrine, are yet formidable. Although the doctrine does not in theory involve the courts in case-by-case weighing and balancing, it nonetheless necessitates difficult distinctions that may, in hard cases, mask an underlying process of judicial policymaking.

Difficulty of administration is not the only problem with the doctrine. If, as suggested earlier, an ideal immunity doctrine minimizes the judiciary's role in the final determination of such important federalism issues, the legal incidence rule seems a failure. The practical effect of the rule is to make the rule itself-a judge-made one-the final determinant of immunity questions.

The courts have essentially two options in federal immunity cases. They can either generally prohibit state taxation of the kind in issue, or generally permit it. Unless it appears that the tax in question unduly interferes with federal functions, in which case immediate prohibition may be indicated, the question of which of the two options is preferable should be decided by asking which course of action is likely to maximize the chances of congressional resolution of the immunity issue. Proponents of the legal incidence rule-the prohibition option-argue that the doctrine serves to maintain the status quo until Congress resolves particular immunity issues. ${ }^{163}$ This view presumes the desirability of the status quo and presumes also that Congress can be expected to debate immunity issues on its own motion. Neither presumption is justified. The desirability of the status quo is the very question of state-federal

${ }^{162}$ See text and notes at notes 64-68 supra.

${ }^{103}$ Tribe, supra note 53, at 705 n.103. 
relations that all agree Congress, not the courts, should decide. By preserving the status quo, the courts do decide immunity questions, at least until Congress acts (or refuses to act) on them. And both history and common sense suggest that the courts, by determining the federal immunity issues in this fashion, in fact decide them permanently: a Congress already overtaxed by more pressing and visible problems is unlikely to confront tax immunity questions until the status quo is withdrawn. ${ }^{164}$

Under the current theory of federal immunity, the presumption embodied in the legal incidence rule would be justified only if the rule implements congressional intent that federal instrumentalities be immunized from legally incident state taxes. Congress, however, has not spoken as to most immunities, and the decisions indicate the inappropriateness of inferring anything from such silence. "Silence of Congress," Chief Justice Stone once wrote, "implies immunity no more than does the silence of the Constitution." 165 The frailty of the inference is further demonstrated by Congress's failure in the past to reenact judge-made immunities upon their withdrawal. ${ }^{166}$

is Tribe, the leading exponent of preserving the status quo, recognizes and uses the force of this conclusion in his attack on the Kern doctrine which permits low-echelon officials in the Executive branch to create tax immunities by contract.

He specifically rejects the authority of the executive to act subject to a check by Congress, reasoning:

[S]uch a procedure would set political inertia against state institutional interests, a result making it unlikely that those interests will be adequately protected. The relatively low-level ad hoc decisions of government contracting officers do not seem capable of producing the sort of dramatic nationwide erosion of state tax bases that would cause concerted action in Congress.

Id. at 711 n.137.

Tribe argues that a rule preserving the status quo while Congress decides the immunity issue would seem justified "if the harm a state may inflict on a federal instrumentality can be so great as to support injunctive relief, see Osborn v. Bank of the United States, 22 U.S. (9 Wheat.) 738 (1824); Mayo v. United States, 319 U.S. 441 (1943), and if courts are not in a good position to assess what a reasonable infringement of federal intersts might be . . . ." Id. at 705 n.103. There are several difficulties with this argument. First, it has been demonstrated that the harm that will be inflicted in fact is not constitutionally impermissible. Further, injunctive relief was appropriate in Mayo and Osborn because of threatened regulatory action, not attempted taxation. Third, the courts regularly assess infringements on federal interests in challenges to indirect taxation. See text and notes at notes 64-68 supra. Finally, the real question seems to be whether the incremental interim protection afforded the federal government by the incidence doctrine justifies the doctrine's practical effect of removing immunity issues from the political sphere and lodging their decision with the judiciary.

is Graves v. New York ex rel. O'Keefe, 306 U.S. 466, 480 (1939). See also Powell, supra note 135 , at $666-71$.

Iu Congress declined to pass legislation immunizing government contractors performing under cost-plus-fixed-fees from state taxation after the Dravo decision. See Powell, supra note 
In the absence of congressional direction, the courts, when faced with the question of a federal immunity that is not demanded by the burdensomeness of the tax in question, should refrain from usurping, even temporarily, the legislative office of deciding the issue. No compelling defense of the rule can be advanced. ${ }^{167}$ Thus, the legal incidence rule should be abandoned.

\section{A NoNDISCRIMINATION STANDARD}

The root of federal tax immunity doctrine has always been the canard that "the power to tax is the power to destroy." Chief Justice Marshall did not, in McCulloch and Weston, hold that the immunity of federal instrumentalities from state taxation was implicit in the Congressional action in creating federal instrumentalities. Marshall saw the issue in terms of the clashing of two blind forces: federal law (in the form of federal operations) and state law (in the form of state tax laws). It was never, for Marshall, a question of

135 , at 663 , concluding that it is questionable whether "the Court should protect the federal fisc on purely formal grounds when it does not do so on substantial grounds and when Congress rejects proposals to prevent the states from profiting greatly at national expense." See also Alabama v. King \& Boozer, 314 U.S. 1, 8 n.1 (1941). Another obvious example is congressional failure to reenact the state income tax immunities of federal employees withdrawn by Graves v. New York ex rel. O'Keefe, 306 U.S. 466, 480 (1939).

107 The practical difficulties of assessing and collecting taxes from the fedeal government have been cited as indicia of "cogent policy reasons" for immunity. Hellerstein, supra note 101 , at 1454. Assessment of federal property is not a really formidable problem. First, assessment is only required for a limited category of taxation. The state could impose many taxes on the federal government-sales taxes for instance-without need for assessment. Even when assessment may be required, decisions in the field of state taxation not legally incident on the federal government reveal that assessment is ordinarily not problematic, and is certainly an insufficient justification for extending immunities not otherwise constitutionally required. See, e.g., United States v. City of Detroit, 355 U.S. 466 (1957) (upholding user charges based upon the value of real property owned by the United States).

The suggestion that collection of taxes assessed against the federal government would be hampered by the federal government's immunity from suit and the added immunity from state regulatory action is similarly unpresuasive. First, resort to such remedies is only required if the taxpayer is recalcitrant. In the interests of comity, it is quite possible that the government would simply pay taxes that the courts found owing without attempting to avoid its legal obligations through reliance on other federal immunities. Even if this prediction of federal compliance were unwarranted, sovereign immunity from suit does not render state taxation of the national government a futile exercise. Sovereign immunity from suit is often easily circumvented. See, e.g., United States v. Shaw, 309 U.S. 495, 501 (1940) suggesting the possibility of counterclaims in a federal suit against the state (which obviously could be induced by nonpayment of a federal tax).

Furthermore, the current legal incidence doctrine, by not equating legal incidence and legal liability for the tax, operates to preclude some taxation that would be recoverable from private parties unprotected by sovereign immunity from suit. See United States v. Mississippi Tax Comm'n, 421 U.S. 599 (1975), where the tax was found unconstitutional even though the party legally obligated under the statute, and therefore the party that would be subject to suit by the state for nonpayment, was a private party subject to suit by the state. 
reconciling the two in some way. Rather it was simply a question which of the two would prevail, and the supremacy clause of the Constitution easily resolved that question.

Once it is recognized, however, that the courts can practicably police state taxation - that, in Justice Holmes's words, "[ $t$ ]he power to tax is not the power to destroy while this Court sits"188_the issue posed for the first time in $\mathrm{McC}$ Culloch appears in a much different light. Chief Justice Marshall might be criticized for having given up too easily on the possibility of effective judicial supervision. Justice Johnson, in contrast, did not. He suggested at the outset, in his Weston dissent, that state taxation could easily be kept within its "legitimate use" by the judiciary if the courts simply demanded that states not tax federal instrumentalities discriminatorily. ${ }^{169}$

The nondiscrimination principle did not disappear with Marshall's victory in Weston. One hundred years later, Chief Justice Hughes resurrected it $^{170}$ and made it a cornerstone of federal immunity law, the principal standard by which the courts determine immunity from taxes that are not legally incident on the federal government. And in 1968, in his dissenting opinion in First Agricultural National Bank v. State Tax Commission, ${ }^{171}$ Justice Marshall, joined by Justices Harlan and Stewart, urged that the nondiscrimination test be generalized to cover all cases of claimed federal tax immunities. ${ }^{172}$

The adoption of the nondiscrimination principle in the areas of immunity from non-incident state taxation, ${ }^{173}$ state immunity from federal taxation, ${ }^{174}$ and commerce clause limitations on state taxation of interstate commerce ${ }^{175}$ attests to its success as a tool for accommodating state and federal interests. Since the principle

"* Panhandle Oil Co. v. Mississippi ex rel. Knox, 277 U.S. 218, 233 (1928) (dissenting opinion).

16. Concerning the tax struck down in the Weston case, Justice Johnson declared,

Why should not the stock of the United States, when it becomes mixed up with he capital of its citizens, become subject to taxation in common with other capital? . . . No one imagines, that it is to be singled out and marked as an object of persecution, and that a law professing to tax, will be permitted to destroy ....

Weston v. City Council, 27 U.S. (2 Pet.) 449, 473 (1829) (Johnson. J., dissenting).

170 See text and notes at notes 44-55 supra.

171 392 U.S. 339 (1968).

172 Id. at 352 (Marshall, J., dissenting).

173 E.g., Alabama v. King \& Boozer, 314 U.S. 1 (1941).

in Massachusetts v. United States, 98 S. Ct. 1153 (1978).

175 Complete Auto Transit, Inc. v. Brady, 430 U.S. 274 (1977). Equally apt here is Justice Brennan's conclusion in Massachusetts v. United States, 98 S. Ct. 1153, 1167 n.21 (1978), that the successful use of the immunity standard in the area of state taxation of interstate commerce gave "no reason to suppose that the Court will have any different experience in applying this test" to state immunity from federal taxation. 
would merely forbid unequal tax treatment of federal instrumentalities, it can operate to deny states only the power to abuse the taxing power. Concomitantly, the principle would adequately protect federal interests. In the recent case of Massachusetts $v$. United States, ${ }^{176}$ a state immunity case, Justice Brennan observed that the nondiscriminatory character of the challenged federal tax served to "minimize, if not eliminate entirely, the basis for a conclusion that [the tax] might be an abusive exercise of the taxing power."177

If the nondistrimination principle is to perform its protective function adequately, and without undue sacrifice of state interests, it is important that the courts implement it properly. The recent decision by a three-judge district court in United States $v$. Montana, ${ }^{178}$ reveals a certain confusion about the role of a nondiscrimination test. Although the case concerned a tax that is not legally incident on the federal government, the principles applicable to such taxes should not differ from the standards that would be applied to taxes that fall directly on the government. The court in the Montana case invalidated a state tax imposed on the gross receipts of all public contractors. ${ }^{179}$ No equivalent tax is imposed on contractors doing business with nongovernmental entities. ${ }^{180}$ The court struck down the tax on the ground that it discriminates against the federal government and in favor of the state. ${ }^{181}$ Although the tax is levied against both state and federal contractors, it imposes no burden on the state, for the state receives the revenues generated by the tax.

The Montana case was correctly decided, not because the tax discriminates in favor of the state, but because, as the court majority also noted, ${ }^{182}$ the tax discriminates between federal and private contracting. Even so, the court misunderstood the function of the nondiscrimination principle. It found the tax impermissibly discriminatory in favor of private contracting because the state could give no legitimate justification for separately classifying government contractors. However, the reasonableness of the classification, though relevant for equal protection purposes, should be irrelevant to determining discrimination for federal immunity purposes. The

${ }^{176}$ Massachusetts v. United States, 98 S. Ct. 1153 (1978).

in Id. at 1167.

123 437 F. Supp. 354 (D. Mont. 1977), cert. granted, 46 U.S.L.W. 3719 (U.S. May 22, 1978).

17 Id.

120 Id. at 358.

iss Id. at 359 .

isz Id. at 360 . 
function of the nondiscrimination principle in this area is to ensure federal interests a form of indirect political representation. ${ }^{183}$ To this end, courts should scrutinize the state tax scheme to see if the tax burdens a sufficiently large class of private persons and entities. If it does not, the federal government enjoys no safeguards against abuse, and the statute should fall, no matter how rational its classifications. ${ }^{184}$ For the same reason, it is unimportant whether the tax purports to burden the state as well. As the dissenting judge in Montana pointed out, ${ }^{185}$ any state taxation burdening federal operations affects state and federal interests unequally, for the state fully recaptures any tax burden imposed on its agents.

To the extent that nondiscrimination scrutiny without more might seem underprotective of federal interests, the courts should supplement it with noninterference standards. In the area of state immunity from federal taxation, it will be recalled, there seems to be a residual noninterference limitation. ${ }^{186}$ In New York v. United States $^{\mathbf{1 8 7}}$ both Justice Frankfurter and Chief Justice Stone intimated that even nondiscriminatory taxation that burdens vital governmental functions would be prohibited. A state could conceivably impose a nondiscriminatory tax on federal instrumentalities under circumstances in which the tax would unduly interfere with vital federal operations. In such a case an unsupplemented nondiscrimination rule might unwisely prevent judicial intervention.

The simple nondiscrimination/noninterference standard does not raise the institutional difficulties that plague the legal incidence rule. The nondiscrimination standard is eminently suited to judicial use. The federal courts have applied it for over forty years in assessing the constitutionality of state taxes indirectly burdening the federal government, ${ }^{188}$ and for over thirty years in the area of state

(ns See United States v. County of Fresno, 429 U.S. 452, 463 n.11 (1977).

isi Even though the level of interference engendered by a particular tax might be slight, as in the Montana case, to permit the tax despite its discriminatory impact would completely remove the most efficient means of preventing abusive taxation. Although the judiciary and Congress could still function as guardians of federal interests, the burden of such a guardianship, unassisted by the state political process, would be both substantial and unwarranted. Political representation, whether direct or indirect, has historically been so firmly prerequisite to taxation, see McCulloch v. Maryland, 17 U.S. (4 Wheat.) 316, 428 (1819), that the states can make no compelling claim for the need to tax the federal government without similarly taxing its own constituents. See United States v. County of Fresno, 429 U.S. 547, 463 n.11 (1977).

iss 437 F. Supp. at $364-65$.

iM See text and notes at notes 77-83 supra.

187326 U.S. 572 (1946).

$18 \times$ The nondiscrimination principle was first applied in James v. Dravo Contracting Co., 302 U.S. 134 (1937). 
immunity from federal taxation. ${ }^{189}$ And adoption of the nondiscrimination test will relinquish to the proper branch of the government the task of weighing the competing interests at stake in the intergovernmental tax immunity area. The test is primarily a tool for judicial policing of state taxation efforts, and would prohibit only the kind of taxation that is necessarily hostile to federal interests. The nondiscrimination standard reserves for Congress the decision whether to immunize particular federal instrumentalities from nondiscriminatory state taxes, or whether to immunize all federal instrumentalities from particular kinds of nondiscriminatory state taxes.

\section{CoNCLUSION}

In 1945, Professor Powell surveyed the legal incidence rule of federal tax immunity and declared: "[T] the Supreme Court is continuing to draw is a line of form rather than substance ...."180 Over thirty years later, the rule yet persists. The doctrine has little to recommend it, and most attempts to justify it seem strained rationalizations. The difficulty in justifying the legal incidence doctrine is not surprising in light of its provenance: the doctrine would never have existed but for John Marshall's mistaken belief that the power to tax is, for all practical purposes, the power to destroy. Perhaps the best that can be said for the rule is the observation once made by the rule's most vigorous defender, Justice Frankfurter: "A principle with the uninterrupted historic longevity attributable to the immunity of government property from state taxation has a momentum of authority ."191 But the mode of immunity adjudication which sustained the doctrine for decades is rapidly disappearing from all areas of constitutional tax immunity law. After the Supreme Court's decisions in Michelin and Complete Auto Transit, incidence doctrine can no longer claim the momentum of authority. The Supreme Court should end a century and a half of conceptualist jurisprudence in this area by abandoning the last vestige of absolute tax immunity and embracing the nondiscrimination principle.

Maureen Mahoney

$18 \mathrm{~T}$ The principle was endorsed unambiguously by less than a majority of the Justices in New York v. United States, 326 U.S. 572, 586 (1946) (Stone, C.J., concurring), but the Court seems to have embraced the nondiscrimination principle in Massachusetts v. United States, 98 S.Ct. 1153 (1977).

190 See generally Powell, The Remnant of Intergovernmental Tax Immunities, 58 HaRv. L. REv. 757, 787 (1945). J.).

131 City of Detroit v. Murray Corp. of America, 355 U.S. 489, 503 (1958) (Frankfurter, 